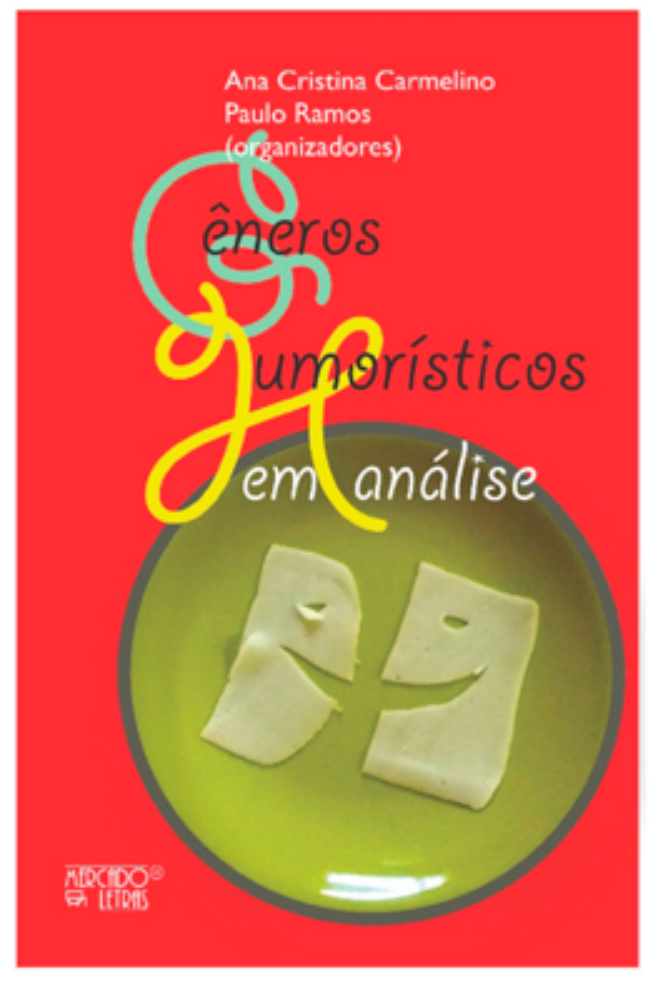

\title{
Humor e ensino: reflexões necessárias
}

\author{
Márcio Antônio Gatti ${ }^{1}$ \\ Universidade Federal de São Carlos
}

Publicado pela editora Mercado de Letras, o livro Gêneros humorísticos em análise, organizado por Ana Cristina Carmelino e Paulo Ramos (2018), reúne capitulos de pesquisadores brasileiros que se dedicam a produzir análises e orientações de aplicação para o ensino dos gêneros humorísticos abordados.

Dividido em duas partes - "gêneros necessariamente humorísticos" e "gêneros eventualmente humoristicos" - o livro faz um apanhado de diversos gêneros (os organizadores deixam claro que utilizarão o termo "gênero" para abarcar as diversas correntes teóricas dos estudos da linguagem e literatura que tratam do assunto e que estão presentes no livro), desde os mais tradicionais, como as piadas, por exemplo,

\footnotetext{
1 Professor da UFSCar - campus Sorocaba. Doutor em Linguística. Email: maggatti@ufscar.br. ORCiD: https://orcid.org/0000-0001-9902-2856.
} 
até os mais recentes ou recém reinventados como os esquetes, os memes e os perfis fakes de redes sociais digitais.

Trata-se de um modo interessante de organizar a obra, dadas as especificidades do humor, que, além de se manifestar em gêneros de certo modo tradicionais, atravessa vários gêneros, estando presente em outros campos, como na literatura, no cinema etc. Separar os gêneros em necessariamente humorísticos e eventualmente humorísticos, no entanto, pode esbarrar nas restrições de qualquer classificação e no modo como os gêneros vão se estabelecendo nos meios de comunicação atuais, sobretudo nas redes sociais. Por isso, é peculiar que o gênero desnotícia ou noticia satírica (conforme a autora do capítulo, Silvana Maria Calixto de Lima) esteja na seção de gêneros eventualmente humorísticos, posto que este tem aparentemente se consagrado como um gênero contemporâneo do humor, inclusive com diversos sites, páginas e demais espaços especializados em sua produção, como bem destaca a autora. E, embora simulem uma noticia, sua estratégia é enganar pela cenografia pseudojornalística - o que é uma de suas características constituintes.

Sobre o propósito principal do livro (o debate sobre o humor no ensino), o público em geral e sobretudo docentes da educação básica encontrarão, além dos capítulos que se dedicam às reflexões sobre o humor no ensino, uma boa ferramenta para aprofundamento nos temas abordados: os capítulos contam com as seções "Saiba Mais" que permitem que o leitor tenha acesso a outros dados, fontes, definições e conceitos.

As propostas de aplicação no ensino contidas nos capítulos são ora mais explícitas e bem detalhadas ora mais implicitas ou norteadoras. A proposta apresentada no capítulo sobre filmes, por exemplo, é bem detalhada e explicita toda uma sequência didática possivel, com objetivos evidenciados e ancorados em uma perspectiva teórica e em uma concepção de ensino de língua materna, outros capítulos, como o que trata de memes, são mais norteadores. Este talvez seja o gênero mais problemático, dada a sua instabilidade, e a sua ligação intrinseca com os dispositivos tecnológicos contemporâneos e os mídiuns digitais online. Neste capítulo, as análises orbitam em torno da noção de inferência, destacando a importância do conhecimento prévio e também da intertextualidade. A relevância para o ensino, embora haja sugestões diretas aos professores, dá-se justamente pelas análises efetuadas a partir de uma perspectiva teórica e que mostra a aplicabilidade 
das noções já mencionadas, constituindo-se como importante material de consulta sobre esse gênero tão atual.

Merece também destaque o modo como, em vários capítulos, uma concepção de escola toma corpo. Cito como exemplos o capitulo que trata de piadas e o que aborda o esquete (o primeiro de Sírio Possenti e o segundo de Ana Cristina Carmelino). Além das propostas mais diretas de aplicação em sala de aula, podemos encontrar, nestes dois capítulos, uma concepção de escola. Ao defender que gêneros como a piada e o esquete sejam estudados - ambos gêneros que tratam geralmente de questões polêmicas - os autores dos dois capitulos deixam claro que a escola não deve se apartar das questões polêmicas de uma sociedade; ao contrário, deve encará-las e estudá-las para a sua compreensão.

Entrando nos gêneros que se relacionam com o foco e o escopo deste periódico, um capítulo do livro se dedica a fazer discussões sobre tiras cômicas (de autoria de Paulo Ramos) e outro se dedica às charges (de autoria de Maria Cristina de Moraes Taffarello).

No capítulo sobre tiras cômicas, a proposta para o ensino é mais norteadora. Apresenta uma série de questionamentos sobre a inserção do gênero nas salas de aula, como, por exemplo, se o texto multimodal é o mais adequado para trabalhar com o tema e a sequência didática em que está inserido. E com razão: muitas vezes, tiras cômicas ou somente ilustram questões que pouco dialogam com ela ou são tratadas de modo tão mecânico (como em aulas de gramática tradicional, por exemplo) e pouco aprofundado, que acabam afastando os alunos de sua leitura.

O professor que queira encontrar material de trabalho no capítulo pode, a princípio, observar o que se diz sobre a intertextualidade, sobre o funcionamento de redes sociais e, claro, sobre tiras cômicas, nas atuais condições de produção desse gênero - segundo o autor, hoje mais amplamente publicadas na internet que em seu suporte tradicional, o jornal. E com uma discussão em torno de tiras e internet, o autor apresenta os dados que analisa: todas as tiras tratam da internet e da vida em torno dos dispositivos que a acessam, como os smartphones, por exemplo.

A exemplo do capítulo sobre tiras, o que trata de charges incorpora o tema do ensino paulatinamente. Faz boa recuperação histórica do gênero no Brasil e no mundo, bem como explicita suas caracteristicas formais e funcionais - aspectos que podem e devem ser explorados como questão para o ensino. 
O capitulo amplia, com sua atenta análise textual/discursiva de uma charge utilizada em uma prova de história do ENEM, a acanhada abordagem do material produzida pelo exame. Também incorpora à análise elementos históricos necessários para a interpretação do texto em questão, e com isso fornece elementos (que podem ser inclusive procedimentais) a professores que trabalham com o gênero, aliando à análise de elementos como a inferência.

Defende, a partir da análise produzida, que a teoria dos scripts formulada por Raskin pode ser aplicada também para os textos multimodais. E analisa outra charge, aplicando tal teoria, defendendo uma análise intertextual que, segundo a autora, é importante para a compreensão do gênero, dadas as suas peculiaridades.

Em resumo, o que se pode dizer sobre o livro é que se trata de um excelente material para professores de lingua materna e para pesquisadores interessados por questões em torno do humor. Vale a leitura. De todos os capitulos.

\section{Referências}

CARMELINO, Ana Cristina; RAMOS, Paulo (org.). Gêneros humorísticos em análise. Campinas: Mercado de Letras, 2018. 